\title{
A note on the occurrence of the encrusting foraminifera Homotrema rubrum in reef sediments from two distinctive hydrodynamic settings
}

\author{
ALTAIR J. MACHADO and SIMONE S. MORAES \\ Laboratório de Estudos Costeiros, Curso de Pós-Graduação em Geologia, CPGG/Instituto de Geociências/UFBA \\ 40210-340 Salvador, BA, Brasil \\ Manuscript received on October 16, 2001; accepted for publication on August 8, 2002; \\ presented by Diogenes A. CAMPos
}

\begin{abstract}
Sediment samples from two different reef environments were analyzed for their foraminiferal content: the Sioba/Rio do Fogo reefs, located in a broad shallow shelf dominated by strong currents (Rio Grande do Norte State), and the Praia do Forte reefs, located in a narrow shelf under the influence of wind-induced waves (Bahia State). The recorded foraminiferal fauna, from forty-six samples, is represented by 113 species, being the encrusting species Homotrema rubrum present in nine samples from the Sioba/Rio do Fogo reefs and in 11 samples from Praia do Forte reefs. Homotrema fragments recovered from Sioba/Rio do Fogo are mostly polished with rounded edges $(51.59 \%)$ and some have a whitish color, whereas the specimens from Praia do Forte reefs are predominantly composed of reddish fragments $(82.41 \%)$ with sharpened points $(63.88 \%)$. The high wave energy on the reef environment of Praia do Forte is responsible for the fragmentation of living Homotrema tests (red color), which are deposited near to their source area. The effects of the strong current system operating in the broad continental shelf of Sioba/Rio do Fogo is the major cause of sediment reworking, producing polished grains accumulated in its reef surroundings.
\end{abstract}

Key words: Homotrema rubrum, reefs, coralline algae, coral.

\section{INTRODUCTION}

Homotrema is a calcareous encrusting foraminifera genus, with a large test (usually more than $8 \mathrm{~mm}$ in diameter), with varied shape (globular, hemispheric) and presenting different types of encrustation: irregular, conic, truncated. The first chamber is branched and/or spiraled, and the last ones are distributed in layers. Irregular openings between lateral walls occur when new chambers are added. These unilocular animals have, when alive, a common reddish color, caused by the pigment decomposition of hosted en-

Correspondence to: Altair de Jesus Machado E-mail: altair@cpgg.ufba.br dossimbionts (Loeblich and Tappan 1964, 1988), but become light-pink to whitish after death (Emiliani 1951). The distribution and growth form of Homotrema tests may be controlled by environmental conditions, particularly the local hydrodynamic energy.

The purpose of this work is to compare the Homotrema specimens collected from two different reef sites which are dominated by distinctive hydrodynamic settings: the Sioba and Rio do Fogo reefs, in northeast Brazil, which are in a broad shallow shelf, dominated by strong currents (Testa 1996), and the Praia do Forte coastal reefs, which are located in a narrow part of the eastern coast of Brazil, 


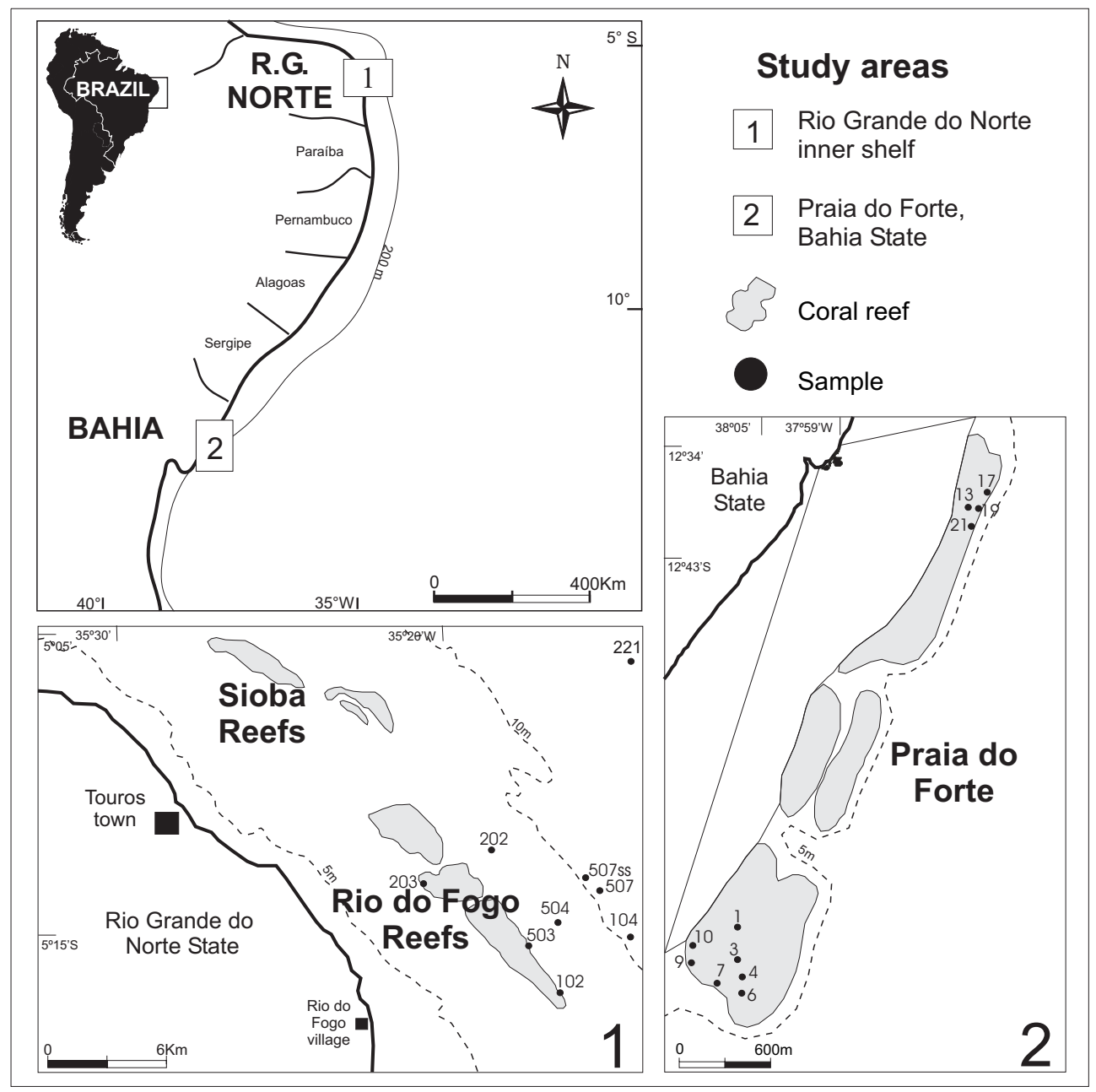

Fig. 1 - Map of the studied reefs with location of the samples containing Homotrema rubrum fragments.

under the influence of wind-induced waves (Dominguez et al. 1992, Bittencourt et al. 2000).

The Sioba and Rio do Fogo reefs are located in the inner continental shelf of the of Rio Grande do Norte State, in northeastern Brazil $\left(5^{\circ} 15^{\prime} \mathrm{S}\right.$ $35^{\circ} 20^{\prime} \mathrm{W}$ ) (Fig. 1). Climate along the whole coast of the state is semi-arid, with average rainfall varying from 600 to $1500 \mathrm{~mm} /$ year (Schultz et al. 1992, Rao et al. 1993). Summer is the dry season, extending from September to February, whilst winter, the wet season, extends from March to August. Temperature of surface waters varies from $26.5^{\circ} \mathrm{C}$ (winter) to $28.5^{\circ} \mathrm{C}$ (summer) (Servain et al. 1990). Salinity values range between 36 and 37\%o (Testa 1996).
The reefs of Praia do Forte are located in the northernmost part of the coast of the Bahia State, in eastern Brazil $\left(12^{\circ} 30^{\prime} \mathrm{S}-38^{\circ} 00^{\prime} \mathrm{W}\right)$ (Fig. 1), a region dominated by a tropical humid climate, where rainfall ranges between 1300 to $1900 \mathrm{~mm} /$ year, and air temperature varies from $23^{\circ} \mathrm{C}$ (winter) to $28^{\circ} \mathrm{C}$ (summer) (Nimer 1989). Dominant easterly winds occur in January and September, northeasterly winds are frequent from October to December and from February to March, whereas strong southeasterly winds occur during wintertime (April to August) (DHN 1993). Temperature of surface waters ranges from $25^{\circ} \mathrm{C}$ in summer, to $28^{\circ} \mathrm{C}$, in wintertime, and salinity varies from 35 to $37 \%$ (DHN 1993). 


\section{MATERIALS AND METHODS}

Samples of reefal sediments were collected in both studied areas during SCUBA diving, using plastic containers. In the Sioba and Rio do Fogo area twenty-four samples were collected from sand accumulations and rodoliths relict deposits, surrounding the reefs. In the Praia do Forte area, twentytwo samples were collected, twelve from the bottom around the reefs and ten from the tidal pools on the partially exposed reef tops.

In the laboratory all samples were washed in fresh water using a 62-mesh sieve, for elimination of salts, dried and stored in plastic bags. From each sample, two hundred specimens of foraminifera were randomly picked and stored in appropriate microfossil slides, for identification under a stereomicroscope. Only the samples having Homotrema specimens were selected for study, e. g., twenty samples - nine from the Sioba/Rio do Fogo area and eleven from Praia do Forte. From the Sioba/Rio do Fogo reefs the selected samples were 102, 104, 202, 203, 221, 503, 504, 507ss and 507, and from Praia do Forte reefs, the samples with the presence of Homotrema were 01, 03, 04, 06, 07, 09, 10, 13, 17, 19 and 21 (see Figure 1).

\section{RESULTS}

One hundred and thirteen foraminifera species were identified in the studied sediment samples, being ninety-one from the Sioba/Rio do Fogo area, and eighty from the samples collected in the Praia do Forte reef sediments. Fifty-eight species were common from both studied areas, thirty-three of them occur only in samples from the Sioba/Rio do Fogo reefs, and twenty-two are registered in the samples from the Praia do Forte reefs area (see Table I).

From the twenty four samples collected from the Sioba/Rio do Fogo reefs, only nine of them have Homotrema fragments, summing a total number of one hundred fifty seven fragments (see Table II). A major part of these fragments (51.59\%) are polished, and 32.12sharpened points. Well-preserved forms $(15.29 \%)$ occur only in three samples (Table II) (Fig. 2).
One hundred and eight specimens of Homotrema were registered in eleven samples from the Praia do Forte reefs (from twenty-two collected) (see Table II); and most of these specimens (63.88\%) have sharpened points. Polished fragments and well-preserved forms represent $18.53 \%$ and $17.59 \%$ respectively, of the identified fragments (Table II, Fig. 2).

Red colored tests predominate both in the Sioba/Rio do Fogo reefs (68.15\%), as well as in the Praia do Forte area $(82.41 \%)$, where they are the dominant colored tests found in the identified specimens (Table II, Fig. 3). Tests with pink color occur only in two samples from Praia do Forte, where both together reach $11.11 \%$ of the analyzed specimens. Whitish fragments are more common in the samples from the Sioba/Rio do Fogo reefs, reaching $31.85 \%$ of all identified specimens.

\section{DISCUSSION AND CONCLUSIONS}

The Sioba/Rio do Fogo studied samples are spreaded in a broader area than the Praia do Forte samples. They represent different reef zones, such as the fore reef (samples 102, 503, 202, 504) and the back reef zone (sample 203), and are also located in more varied depths (from about $5 \mathrm{~m}$ to more than $10 \mathrm{~m}$ ). Most of the Praia do Forte samples were collected in the shallow reef flat zone, in depths less than $5 \mathrm{~m}$. The more diverse types of reef habitats present in the Sioba/Rio do Fogo area are probably the reason for the higher number of foraminifera species found in the Rio Grande do Norte reefs (91) than in the Bahia reefs (80).

Well-preserved reddish Homotrema fragments indicate proximity of their source areas, and polished fragments are evidence of sediment transport and/or effect of high-energy conditions. In both areas, living and/or recent dead Homotrema specimens (red colored) dominate, which is an indication that most samples were collected at or near the original habitats.

In the Sioba/Rio do Fogo reefs polished fragments dominate (51.59\%). The effects of the strong current system operating in the broad continental 
TABLE I

Foraminifera species identified in the studied areas.

\begin{tabular}{|c|c|c|c|c|c|}
\hline Species & $\begin{array}{c}\text { Sioba/ } \\
\text { Rio do } \\
\text { Fogo }\end{array}$ & $\begin{array}{l}\text { Forte } \\
\text { Beach }\end{array}$ & Species & $\begin{array}{c}\text { Sioba/ } \\
\text { Rio do } \\
\text { Fogo }\end{array}$ & $\begin{array}{l}\text { Forte } \\
\text { Beach }\end{array}$ \\
\hline Homotrema rubrum & $\mathrm{X}$ & $\mathrm{X}$ & Quinqueloculina bicornis & $\mathrm{X}$ & $\mathrm{X}$ \\
\hline Ammonia beccarii & $\mathrm{X}$ & $\mathrm{X}$ & Quinqueloculina candeiana & & $\mathrm{X}$ \\
\hline Archaias angulatus & $\mathrm{X}$ & $\mathrm{X}$ & Quinqueloculina contorta & $\mathrm{X}$ & $\mathrm{X}$ \\
\hline Amphistegina gibbosa & & $\mathrm{X}$ & Quinqueloculina costata & $\mathrm{X}$ & $\mathrm{X}$ \\
\hline Amphistegina lessonii & $\mathrm{X}$ & & Quinqueloculina crassa & $\mathrm{X}$ & $\mathrm{X}$ \\
\hline Articulina mucronata & $\mathrm{X}$ & $\mathrm{X}$ & Quinqueloculina cuvierina & $\mathrm{X}$ & $\mathrm{X}$ \\
\hline Articulina multilocularis & $\mathrm{X}$ & & Quinqueloculina fusca & $\mathrm{X}$ & $\mathrm{X}$ \\
\hline Bigenerina textularoidea & $\mathrm{X}$ & & Quinqueloculina horrida & $\mathrm{X}$ & $\mathrm{X}$ \\
\hline Bolivina compacta & & $\mathrm{X}$ & Quinqueloculina implexa & & $\mathrm{X}$ \\
\hline Bolivina translucens & $\mathrm{X}$ & & Quinqueloculina lamarckiana & $\mathrm{X}$ & $\mathrm{X}$ \\
\hline Borelis pulchra & $\mathrm{X}$ & & Quinqueloculina microcostata & $\mathrm{X}$ & $\mathrm{X}$ \\
\hline Cancris sagra & & $\mathrm{X}$ & Quinqueloculina moyensis & & $\mathrm{X}$ \\
\hline Cibicides aknerianus & $\mathrm{X}$ & $\mathrm{X}$ & Quinqueloculina reticulata & $\mathrm{X}$ & $\mathrm{X}$ \\
\hline Cibicides pseudogerianus & $\mathrm{X}$ & $\mathrm{X}$ & Quinqueloculina seminulum & $\mathrm{X}$ & $\mathrm{X}$ \\
\hline Clavulina tricarinata & $\mathrm{X}$ & & Quinqueloculina sulcata & $\mathrm{X}$ & $\mathrm{X}$ \\
\hline Cornuspira involvens & & $\mathrm{X}$ & Quinqueloculina parkeri & $\mathrm{X}$ & $\mathrm{X}$ \\
\hline Dentostomina enoplostoma & $\mathrm{X}$ & & Quinqueloculina planciana & $\mathrm{X}$ & \\
\hline Discorbis candeina & & $\mathrm{X}$ & Quinqueloculina polygona & $\mathrm{X}$ & \\
\hline Discorbis mira & $\mathrm{X}$ & $\mathrm{X}$ & Quinqueloculina pricei & $\mathrm{X}$ & $\mathrm{X}$ \\
\hline Discorbis obtusa & $\mathrm{X}$ & $\mathrm{X}$ & Quinqueloculina reticulata & $\mathrm{X}$ & $\mathrm{X}$ \\
\hline Discorbis orbicularis & $\mathrm{X}$ & $\mathrm{X}$ & Quinqueloculina venusta & $\mathrm{X}$ & $\mathrm{X}$ \\
\hline Elphidium articulatum & $\mathrm{X}$ & & Quinqueloculina vulgaris & $\mathrm{X}$ & $\mathrm{X}$ \\
\hline Elphidium crispum & $\mathrm{X}$ & & Reusella spinulosa & & $\mathrm{X}$ \\
\hline Elphidium discoidale & $\mathrm{X}$ & $\mathrm{X}$ & Schlumbergerina alveoliniformis & & $\mathrm{X}$ \\
\hline Elphidium galvestonense & $\mathrm{X}$ & $\mathrm{X}$ & Sigmoilina poeyana & & $\mathrm{X}$ \\
\hline Elphidium poeyanum & $\mathrm{X}$ & $\mathrm{X}$ & Sigmoilina subpoeyana & & $\mathrm{X}$ \\
\hline Elphidium sagrum & & $\mathrm{X}$ & Siphonina pulchra & $\mathrm{X}$ & $\mathrm{X}$ \\
\hline Globigerinoides ruber & $\mathrm{X}$ & $\mathrm{X}$ & Sorites marginalis & $\mathrm{X}$ & $\mathrm{X}$ \\
\hline Hanzawaia bertheloti & & $\mathrm{X}$ & Spiroloculina antilarum & $\mathrm{X}$ & $\mathrm{X}$ \\
\hline Hauerina ocidentalis & $\mathrm{X}$ & & Spiroloculina caduca & $\mathrm{X}$ & $\mathrm{X}$ \\
\hline Heterostegina depressa & $\mathrm{X}$ & & Spiroloculina depressa & $\mathrm{X}$ & \\
\hline Heterostegina suborbicularis & $\mathrm{X}$ & $\mathrm{X}$ & Spiroloculina estebeni & $\mathrm{X}$ & \\
\hline Massilina pernambucensis & $\mathrm{X}$ & & Spiroloculina profunda & $\mathrm{X}$ & \\
\hline Miliolinella australis & $\mathrm{X}$ & & Spiroloculina moesi & $\mathrm{X}$ & $\mathrm{X}$ \\
\hline Miliolinella labiosa & $\mathrm{X}$ & $\mathrm{X}$ & Textularia agglutinans & $\mathrm{X}$ & $\mathrm{X}$ \\
\hline Miliolinella suborbicularis & $\mathrm{X}$ & $\mathrm{X}$ & Textularia candeiana & & $\mathrm{X}$ \\
\hline Miliolinella subrotunda & & $\mathrm{X}$ & Textularia earlandi & & $\mathrm{X}$ \\
\hline Nonion grateloupi & $\mathrm{X}$ & $\mathrm{x}$ & Textularia gramen & $\mathrm{X}$ & $\mathrm{X}$ \\
\hline Nonionella atlantica & $\mathrm{X}$ & $\mathrm{X}$ & Textularia kerimbaensis & $\mathrm{X}$ & \\
\hline Oolina hexagona & $\mathrm{X}$ & & Tretomphalus atlanticus & $\mathrm{X}$ & \\
\hline
\end{tabular}


TABLE I (continuation)

\begin{tabular}{l|c|c|l|c|c}
\hline Species & $\begin{array}{c}\text { Sioba/ } \\
\text { Rio do } \\
\text { Fogo }\end{array}$ & $\begin{array}{c}\text { Forte } \\
\text { Beach }\end{array}$ & Species & $\begin{array}{c}\text { Sioba/ } \\
\text { Rio do } \\
\text { Fogo }\end{array}$ & $\begin{array}{c}\text { Forte } \\
\text { Beach }\end{array}$ \\
\hline Penereroplis bradyi & $\mathrm{X}$ & $\mathrm{X}$ & Tretomphalus bulloides & $\mathrm{X}$ & $\mathrm{X}$ \\
Peneroplis carinatus & $\mathrm{X}$ & $\mathrm{X}$ & Triloculina bicarinata & $\mathrm{X}$ & \\
Peneroplis pertusus & $\mathrm{X}$ & $\mathrm{X}$ & Triloculina carinata & $\mathrm{X}$ & \\
Peneroplis proteus & $\mathrm{X}$ & & Triloculina gracilis & & $\mathrm{X}$ \\
Planorbulina acervalis & $\mathrm{X}$ & & Triloculina laevigata & & $\mathrm{X}$ \\
Planorbulina mediterranensis & $\mathrm{X}$ & $\mathrm{X}$ & Triloculina linnaeana & $\mathrm{X}$ & $\mathrm{X}$ \\
Poroeponides lateralis & $\mathrm{X}$ & $\mathrm{X}$ & Triloculina lutea & & $\mathrm{X}$ \\
Pyrgo alata & $\mathrm{X}$ & & Triloculina oblonga & $\mathrm{X}$ & $\mathrm{X}$ \\
Pyrgo bulloides & $\mathrm{X}$ & $\mathrm{X}$ & Triloculina planciana & & $\mathrm{X}$ \\
Pyrgo denticulata & $\mathrm{X}$ & & Triloculina rosea & & $\mathrm{X}$ \\
Pyrgo elongata & $\mathrm{X}$ & & Triloculina sommeri & $\mathrm{X}$ & $\mathrm{X}$ \\
Pyrgo patagonica & $\mathrm{X}$ & $\mathrm{X}$ & Triloculina subrotunda & $\mathrm{X}$ & $\mathrm{X}$ \\
Pyrgo subsphaerica & $\mathrm{X}$ & $\mathrm{X}$ & Triloculina typica & $\mathrm{X}$ & \\
Pyrgo tainanensis & $\mathrm{X}$ & & Triloculina tricarinata & $\mathrm{X}$ & $\mathrm{X}$ \\
Quinqueloculina agglutinata & $\mathrm{X}$ & & Triloculina trigonula & $\mathrm{X}$ & $\mathrm{X}$ \\
Quinqueloculina angulata & $\mathrm{X}$ & $\mathrm{X}$ & Wiesnerella auriculata & $\mathrm{X}$ & \\
Quinqueloculina australis & $\mathrm{X}$ & & & & \\
\hline
\end{tabular}

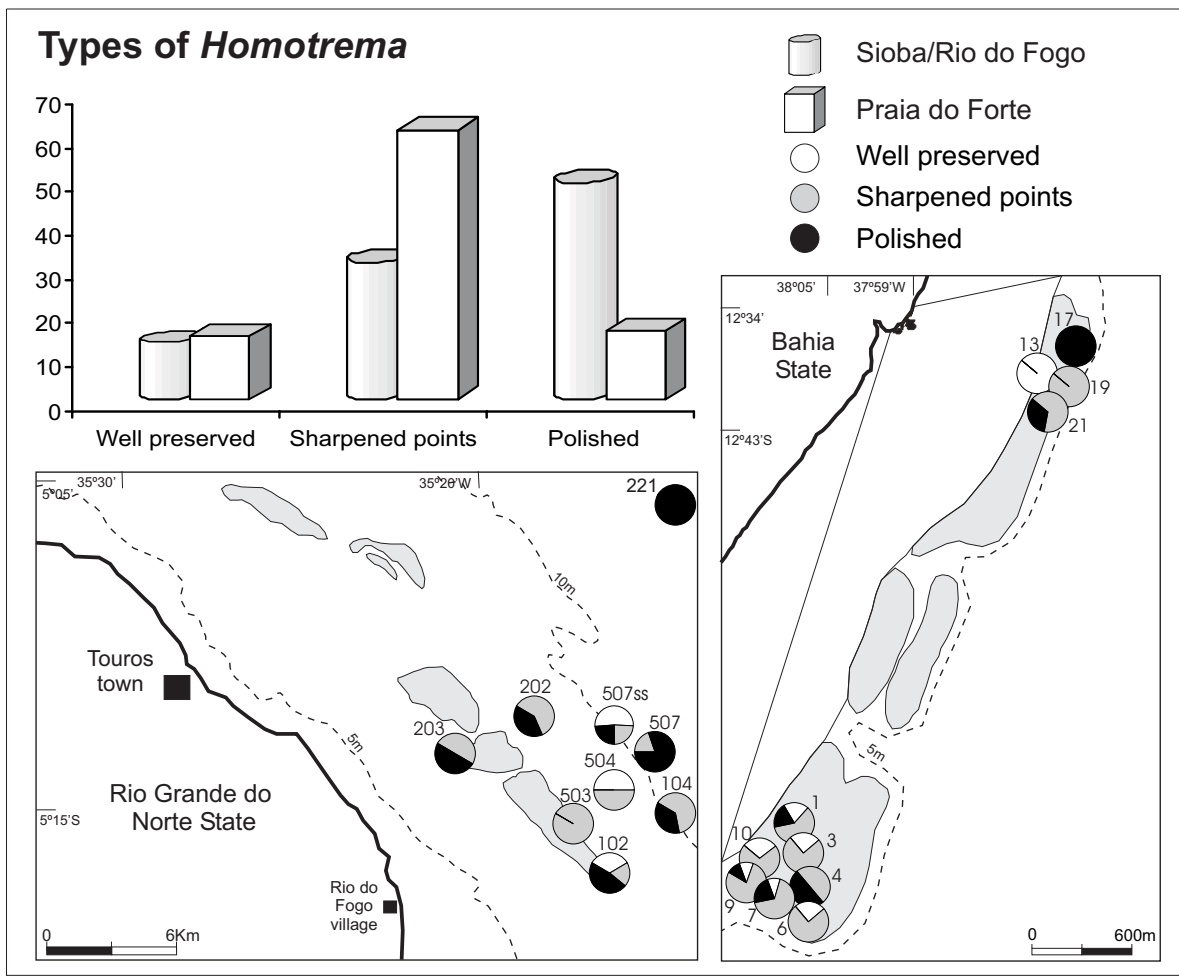

Fig. 2 - Distribution of the major types of Homotrema fragments found in the studied reef areas. 
TABLE II

Number of specimens of Homotrema (fragments) and percentage of their major types and colors found in the samples from Sioba/ Rio do Fogo and Praia do Forte reefs.

\begin{tabular}{|c|c|c|c|c|c|c|c|c|}
\hline & Samples & $\begin{array}{c}\text { Number } \\
\text { of } \\
\text { specimens }\end{array}$ & $\begin{array}{c}\text { Well } \\
\text { preserved } \\
\text { fragments } \\
\quad(\%)\end{array}$ & $\begin{array}{c}\text { Sharpen } \\
\text { points } \\
(\%)\end{array}$ & $\begin{array}{c}\text { Polished } \\
(\%)\end{array}$ & $\begin{array}{l}\text { Red } \\
(\%)\end{array}$ & $\begin{array}{l}\text { Pink } \\
(\%)\end{array}$ & $\begin{array}{c}\text { White } \\
(\%)\end{array}$ \\
\hline & 102 & 21 & 33.33 & 19.05 & 47.62 & - & - & 100.00 \\
\hline & 104 & 22 & - & 63.64 & 36.36 & 36.36 & - & 63.64 \\
\hline \multirow[t]{2}{*}{ Sioba / } & 202 & 10 & - & 60.00 & 40.00 & 100.00 & - & - \\
\hline & 203 & 06 & - & 50.00 & 50.00 & 100.00 & - & - \\
\hline \multirow[t]{2}{*}{ Rio do } & 221 & 08 & - & - & 100.00 & 25.00 & - & 75.00 \\
\hline & 503 & 06 & - & 100.00 & - & 83.33 & - & 16.67 \\
\hline \multirow[t]{6}{*}{ Fogo } & 504 & 04 & 50.00 & 50.00 & - & 50.00 & - & 50.00 \\
\hline & $507 \mathrm{ss}$ & 29 & 51.72 & 24.17 & 24.14 & 100.00 & - & - \\
\hline & 507 & 51 & - & 19.61 & 80.39 & 88.24 & - & 11.76 \\
\hline & Total & 157 & 15.29 & 33.12 & 51.59 & 68.15 & - & 31.85 \\
\hline & 01 & 12 & 25.00 & 75.00 & 25.00 & 100.00 & - & - \\
\hline & 03 & 4 & 25.00 & 75.00 & - & 100.00 & - & - \\
\hline \multirow[t]{3}{*}{ Praia } & 04 & 4 & - & 50.00 & 50.00 & 50.00 & 50.00 & - \\
\hline & 06 & 15 & 25.00 & 75.00 & - & 66.67 & - & 33.33 \\
\hline & 07 & 40 & 10.00 & 67.50 & 22.50 & 75.00 & 25.00 & - \\
\hline \multirow[t]{3}{*}{ do } & 09 & 9 & 11.11 & 77.78 & 11.11 & 100.00 & - & - \\
\hline & 10 & 14 & 28.57 & 71.43 & - & 100.00 & - & - \\
\hline & 13 & 1 & 100.00 & - & - & 100.00 & - & - \\
\hline \multirow[t]{4}{*}{ Forte } & 17 & 4 & - & - & 100.00 & 80.00 & - & 20.00 \\
\hline & 19 & 2 & - & 100.00 & - & 100.00 & & - \\
\hline & 21 & 3 & - & 66.67 & 33.33 & 80.00 & - & 20.00 \\
\hline & Total & 108 & 17.59 & 63.88 & 18.53 & 82.41 & 11.11 & 6.48 \\
\hline
\end{tabular}

shelf off Rio Grande do Norte State, is the major cause of reworking of the sediment that accumulate on the surrounding reefs, producing polished grains, among them the Homotrema fragments.

In the Praia do Forte area most Homotrema fragments have a reddish color $(82.41 \%)$ and are broken with sharpen points $(63.88 \%)$. The high wave energy on this reef environment is responsible for the fragmentation of the reef structure, which is composed by corals, coralline algae and several encrusting organisms, e. g. Homotrema and vermetid (Nolasco and Leão 1986), producing fragments that are deposited near to their source area.

Figure 4 illustrates the major surface features of Homotrema rubrum fragments described in this work.

\section{ACKNOWLEDGMENTS}

The authors thank Dra. Viviane Testa (UFBA) for the samples from Rio Grande do Norte reefs, and CNPq for fellowship provided to A. J. Machado (Process no. 520577/95-7) and CAPES for fellowship provided to S. S. Moraes.

\section{RESUMO}

Amostras de sedimento, coletadas em dois diferentes ambientes recifais, foram analisadas sob o ponto de vista do seu conteúdo de foraminíferos: os recifes de Sioba/Rio do 


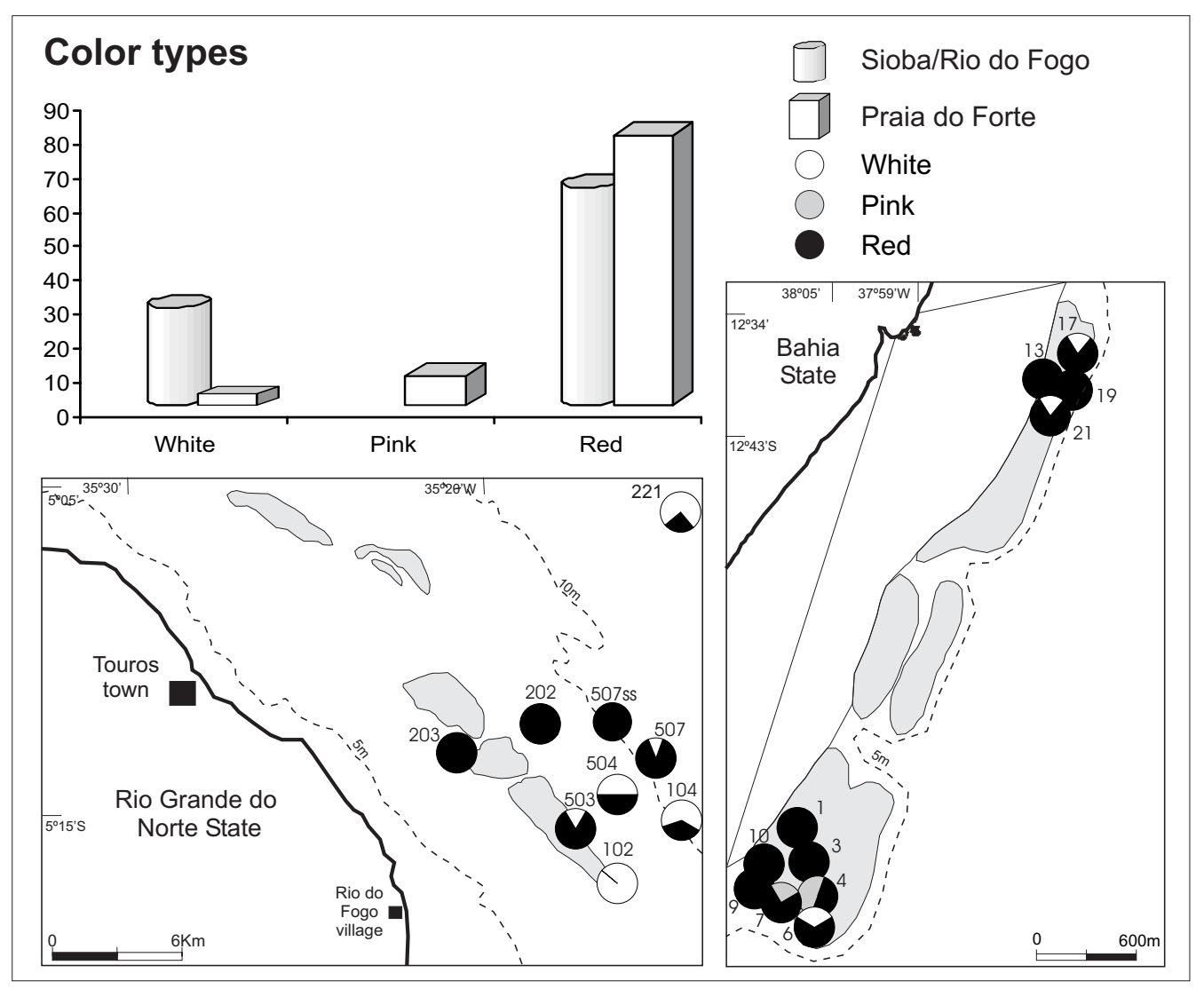

Fig. 3 - Distribution of the Homotrema colored tests found in the studied reef areas.

Fogo, localizados em uma plataforma continental larga e rasa dominada por fortes correntes (Estado do Rio Grande do Norte), e os recifes de Praia do Forte, localizados em uma plataforma continental estreita sob a influência de ondas induzidas pelo vento (Estado da Bahia). A fauna identificada, em quarenta e seis amostras, é representada em cento e treze espécies de foraminíferos, sendo que o foraminífero incrustante Homotrema rubrum ocorre em nove amostras provenientes dos recifes de Sioba/Rio do Fogo e em onze amostras coletadas nos recifes de Praia do Forte. Os fragmentos de Homotrema presentes nas amostras dos recifes de Sioba/Rio do Fogo apresentamse na sua maioria polidos $(51,59 \%)$ e alguns deles com coloração esbranquiçada, enquanto que os espécimes dos recifes de Praia do Forte apresentam-se, na sua maioria, ainda coloridos de vermelho $(82,41 \%)$ e pontiagudos $(63,88 \%)$. A energia das ondas no ambiente recifal de
Praia do Forte é responsável pela fragmentação das testas, ainda vivas (vermelhas), de Homotrema, as quais são depositadas próximo de suas áreas fonte. Os efeitos da ação da energia das correntes no ambiente recifal da ampla plataforma continental de Sioba/Rio do Fogo é a maior causa do retrabalhamento do sedimento, produzindo grãos polidos acumulados nas áreas circunvizinhas dos recifes.

Palavras-chave: Homotrema rubrum, recifes, alga coralina, coral.

\section{REFERENCES}

Bittencourt ACSP, Dominguez JML, Martin L AND Silva IR. 2000. Patterns of Sediment Dispersion Coastwise the State of Bahia-Brazil. An Acad Bras Cienc 72: 210-287.

DHN. 1993. Atlas de Carta Piloto. Diretoria de Hidrografia e Navegação. Marinha do Brazil. (2 ${ }^{\mathrm{a}}$ Edição). 


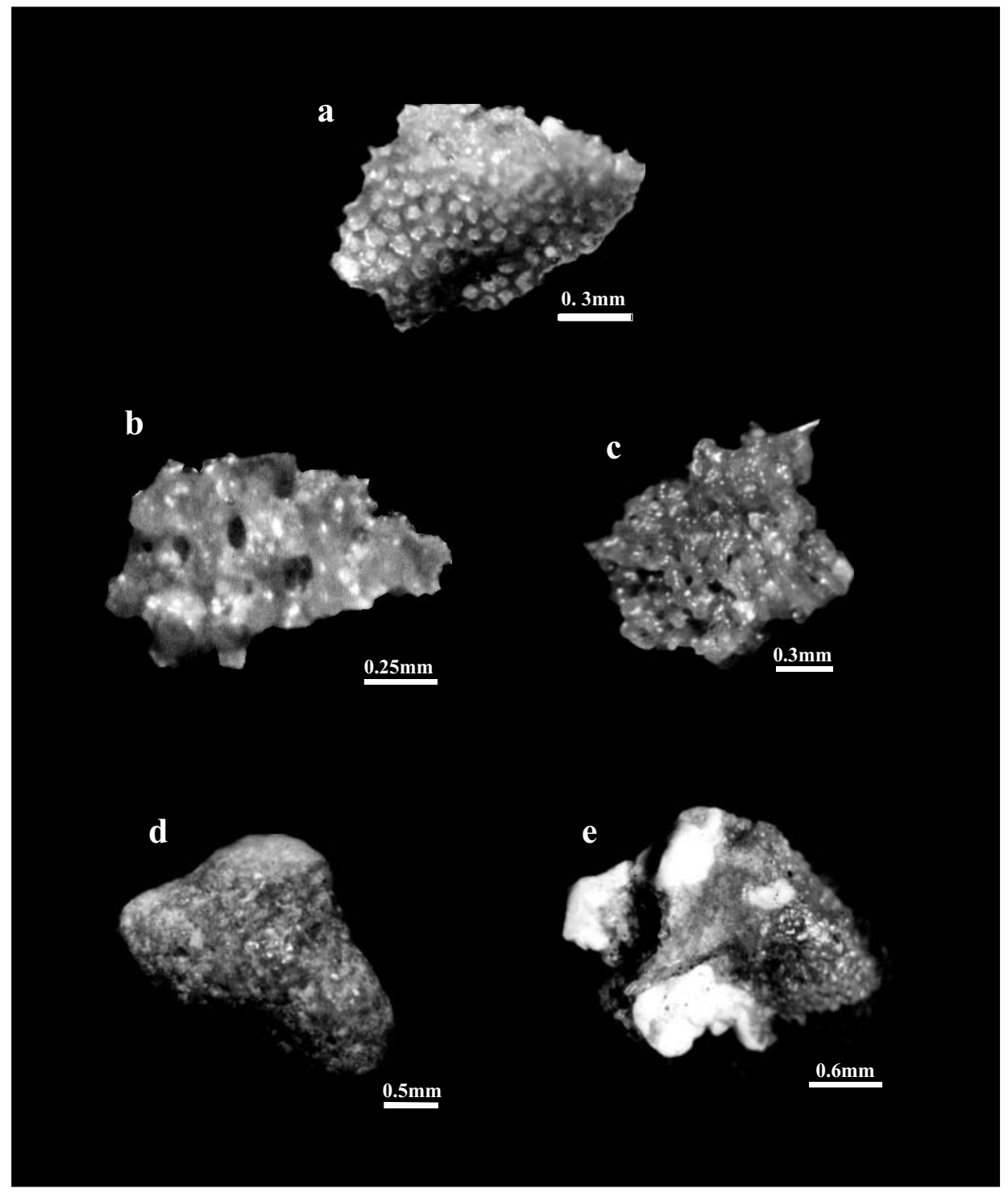

Fig. 4 - Surface features of Homotrema rubrum fragments: a. well preserved chambers, scale $1 \mathrm{~cm}=0.3$ $\mathrm{mm}$; b. sharp pointed grain, scale $1 \mathrm{~cm}=0.25 \mathrm{~mm}$; . hollowed chambers, scale $1 \mathrm{~cm}=0.3 \mathrm{~mm}$; . polished grain, scale $1 \mathrm{~cm}=0.5 \mathrm{~mm}$; e. Homotrema encrusting in coralline algae fragment, scale $1 \mathrm{~cm}=0.6 \mathrm{~mm}$.

Dominguez JML, Bittencourt ACSP And Martin L. 1992. Controls on Quaternary coastal evolution of the east-northeastern coast of Brazil: roles of sealevel history, trade winds and climate. Sediment Geol 80: 213-232.

Emiliani C. 1951. On the species Homotrema rubrum (Lamarck). Cushman Found Foram Res Contr 2: 143-147.
Loeblich AR and TAPpan H. 1964. Treatise on Invertebrate Paleontology. Protista 2(C). Geol Soc of America. 900 p.

LoEBlich AR AND TAPPAN H. 1988. Foraminiferal genera and their classification. Geol Soc of America 1: 970.

Nimer E. 1989. Climatologia do Brasil. IBGE. 422 p.

Nolasco MC AND LEÃo ZMAN. 1986. The carbon- 
ate buildups along the northern coast of the state of Bahia, Brasil. In: RABASSA J. (Ed) Quaternary of South America and Antarctic Peninsula, A.A. Balkema Pub Rotterdam 4: 159-190.

Rao VB, Lima MC and Franchito SH. 1993. Seasonal and interannual variations of rainfall over eastern northeast Brazil. J Climate 6: 1754-1763.

Servain J, Sévea M and Rual P. 1990. Climatological comparison and long-term variations of sea surface temperature over the tropical Atlantic Ocean. J Geophys Res 95: 9421-9431.
Schultz P, Barron EJ and Sloan JL. 1992. Assessment of NCAR general circulation model precipitation in comparison with observations. Palaeogeography, Palaeoclimatology, Palaeoecology (Global and Planetary Change Section) 97: 269-310.

Testa V. 1996. Quaternary Sediments of the Shallow Shelf, Rio Grande do Norte, NE Brazil. PhD thesis. University of London $411 \mathrm{p}$. 